\title{
Experiência clínica na avaliação de 284 casos de erisipela*
}

\section{Clinical experience assessing 284 cases of erisipela*}

\author{
Carlos Henrique de A. Bernardes ${ }^{1}$ \\ Karina Torres Cardoso ${ }^{3}$
}

\author{
João Carlos de Aguiar Augusto² \\ Jaqueline Rodrigues dos Santos ${ }^{3}$
}

\author{
Larissa Torres Cardoso Lopes ${ }^{3}$ \\ Lusimeire Máximo dos Santos ${ }^{3}$
}

\begin{abstract}
Resumo: Os autores analisam algumas características da erisipela no Brasil, alertando para a importância das formas de prevenção de recorrências, que podem ocasionar um quadro clínico de elefantíase, limitando muito as atividades familiares, sociais e profissionais do paciente. Fazem uma análise retrospectiva de 284 casos de erisipela no período de 1995 a 1996, analisando os seguintes fatores: sexo, idade, topografia da lesão, predisposição local e sistêmica, porta de entrada, tratamento, complicações e eventual necessidade de internação. Os resultados mostram que os homens e os obesos são mais atingidos pela doença, a faixa etária com maior incidência é a dos 60 aos 70 anos, e os membros inferiores são os locais de preferência para instalação.

Nesta casuística, a tinha dos pés foi a principal porta de entrada da infecção bacteriana, e, quando o paciente apresentava bolhas necrotizantes, houve necessidade de internação hospitalar para tratamento. Como medicação de escolha e não havendo contra-indicação, a maioria dos casos foi tratada com penicilina benzatina e a cristalina
\end{abstract}

Palavras-chave: Erisipela; Streptococcus

Summary: This study concerns Erysipelas disease in Brazil and is also a warning regarding the importance of preventing its recurrence, which may lead to a clinical picture of elephantiasis and consequent impairment in the domestic, social and professional life of the patient. A retrospective analysis was performed of 284 cases of erysipelas in the period from 1995 to 1996, considering the following features: sex, age, related mapping of the injured tissue, systemic and local predisposition, means of infection, medical treatment, concurrent disease and eventual need for hospitalization. The results showed that males and obese individuals are the most likely to be affected by the disease and especially those from 60 to 70 years old. The inferior members were the most affected by the disease. Skin lesions due to tinea pedis were the main entry site of the bacterial agent. Hospitalization was necessary when the patient presented necrotic lesions. Penicillin G benzathine and crystalline penicillin were the medicines of choice and side effects were not observed in the majority of cases.

Key-words: Erysipelas; streptococcus

Recebido em 21.07.1998. / Received in July, $21^{\text {th }}$ of 1998.

Aprovado pelo Conselho Consultivo e aceito para publicação em 06.03.2001. / Approved by the Consultive Council and accepted for publication in March, $6^{\text {th }}$ of 2001.

* Trabalho realizado no Serviço de Cirurgia Vascular da Santa Casa de Misericórdia de Santos - Faculdade de Ciências Médicas de Santos / Work done at "Serviço de Cirurgia Vascular da

Santa Casa de Misericórdia de Santos - Faculdade de Ciências Médicas de Santos"

Professor Titular da Disciplina de Cirurgia Vascular da Faculdade de Ciências Médicas de Santos. Chefe do Serviço de Cirurgia Vascular da Santa Casa de Misericórdia de Santos / Full Professor of Vascular Surgery at the Santos School of Medicine. Head of the Vascular Surgery Service of the Santa Casa de Misericórdia de Santos.

Assistente do Serviço de Cirurgia Vascular da Santa Casa de Misericórdia de Santos / Assistant at the Vascular Surgery Service of the Santa Casa de Misericórdia de Santos

3cadêmica da Faculdade de Ciências Médicas de Santos / Undergraduate at the Santos School of Medicine 


\section{INTRODUÇÃO}

A erisipela é uma celulite superficial com intenso comprometimento do plexo linfático subjacente e se caracteriza por placas eritematosas acompanhadas de dor e edema. Apresenta, ainda, bordos elevados e enduração que confere à pele aspecto de casca de laranja, conforme observação de Tanaka. Essas lesões expandem-se perifericamente, tornamse quentes e com limite demarcado, dois ou três dias depois do aparecimento dos sintomas gerais, que incluem um período prodômico, em que há brusca elevação da temperatura até $39^{\circ} \mathrm{C}$ ou $40^{\circ} \mathrm{C}$, calafrios, náuseas e intenso mal-estar.

$\mathrm{O}$ agente etiológico mais comum da erisipela é o Streptococcus beta-hemolítico do grupo A (raramente dos grupos C ou G, e, em recém-nascidos, do grupo B), ${ }^{2}$ podendo ocorrer infecção pelo Staphilococcus aureus.

Ocorre em qualquer faixa etária, e o pico se dá entre 60 e 80 anos Os locais mais acometidos são os membros inferiores, seguidos da face e membros superiores. É mais freqüente em pacientes do sexo feminino, sendo observada na maioria dos casos uma porta de entrada bem definida, como úlceras, traumas, micoses superficiais, picadas de inseto e feridas maltratadas.

O diagnóstico é essencialmente clínico, uma vez que o isolamento do agente raramente é conseguido, provavelmente por sua presença escassa ou devido a suas complexas exigências dos meios de cultura.

$\mathrm{Na}$ maioria dos casos existe indicação do uso de penicilina para tratamento da erisipela, mas, quando o paciente apresenta reação alérgica a esse tipo de medicamento, pode-se utilizar a eritromicina.

As complicações mais freqüentes são erisipela bolhosa necrotizante, abscesso, tromboflebite superficial e profunda.

$\mathrm{O}$ aumento da procura do Serviço de Emergência de hospitais e pronto-socorros por parte de pacientes ${ }^{1,3}$ com erisipela motivou a realização deste trabalho sobre o assunto, com o objetivo de orientar os profissionais que trabalham nesses locais a realizar o diagnóstico e tratar adequadamente esses pacientes.

\section{CASUÍSTICA}

Este estudo é uma análise retrospectiva de 284 casos de erisipela tratados no Serviço de Cirurgia Vascular da Santa Casa de Misericórdia de Santos no período de 1995 a 1996.

O diagnóstico de erisipela foi confirmado clinicamente, pela presença de placa com quatro sinais flogísticos clássicos e de bordos bem definidos, acompanhada de febre alta calafrios e adenomegalia.

Foram analisados os seguintes fatores: sexo, idade, topografia da lesão, fatores predisponentes locais e sistêmicos, porta de entrada, tratamento, complicações e necessidade eventual de internação.

\section{RESULTADOS}

Dos 284 pacientes estudados, 130 (45\%) eram do sexo feminino, e 154 (55\%), do sexo masculino.

\section{INTRODUCTION}

Erysipelas is a superficial cellulitis with intense involvement of the subjacent lymphatic plexus and is characterized by erythematous plaque accompanied by pain and edema. It also presents raised borders and induration that confers an orange-peel aspect to the skin, according to the observations of Tanaka. These lesions expand outwards, become hot and have a sharply defined margin, two or three days after onset of the general symptoms, which include a prodromal period, in that there is an abrupt elevation of the temperature reaching $39^{\circ} \mathrm{C}$ or $40^{\circ} \mathrm{C}$ with chills, nausea and intense indisposition.

The most common etiological agent of erysipelas is group A $\beta$-hemolytic Streptococcus (rarely groups $C$ or $G$ and in new born infants group B), ${ }^{2}$ infection by Staphylococcus aureus may also be observed.

It occurs in all age groups, though with a peak between 60 and 80 years. The inferior members are most frequently involved, followed by the face and superior members. It is also more frequent in female patients. In most cases there is a very well-defined entry site, such as ulcers, traumas, superficial mycoses, insect bites and inadequately treated wounds.

Diagnosis is essentially clinical, since isolation of the agent is rarely acheived, probably due to its scarce presence or to the complex requirements of the culture medium.

Penicillin is indicated for most cases of erysipelas, but erythromycin can be used when the patient presents an allergic reaction to this type of medication.

The most frequent complications are bullous necrotizing erysipelas, abscess and superficial and profound thrombophlebitis.

An increase in the attendance of patients with erysipelas at the emergency and first aid services of hospitals ${ }^{1,3}$ motivated this study, with the objective of clarifying the correct diagnosis and appropriate treatment of these patients.

\section{PATIENTS}

This study is a retrospective analysis of 284 cases of erysipelas treated in the Vascular Surgery Service of Santa Casa de Misericórdia de Santos during the period from 1995 to 1996.

The diagnosis of erysipelas was confirmed clinically, by the presence of plaque with four classic inflammatory signs and sharply defined borders, accompanied by high fever, chills and adenomegaly.

The following factors were analyzed: sex, age, related mapping of the injured tissue, local factors and systemic predisposing factors, entry site, treatment, complications and eventual need for hospitalization.

\section{RESULTS}

Of the 284 patients studied, 130 (45\%) were female, and 154 (55\%) male. The disease involved patients in the 
A doença acometeu pacientes da faixa etária de 13 a 87 anos, sendo a média de idade deste estudo 54 anos.

Dos 284 pacientes, todos apresentaram erisipela nos membros inferiores, tendo um deles apresentado também na nádega direita Dos casos analisados, 120 (43\%) tiveram acometimento do membro inferior esquerdo, 113 (40\%) do membro inferior direito, e 50 (17\%) de ambos. Observou-se também que 73 (25\%) casos apresentaram mais de um episódio de erisipela.

Verificou-se neste estudo que 221 (78\%) pacientes tinham algum fator predisponente. Classificados esses fatores em locais e sistêmicos, foram detectados 111(50\%) com fatores locais e $110(50 \%)$ com sistêmicos.

Dos fatores predisponentes locais (111 casos), os autores observaram apenas um (1\%) caso de linfangite crônica, 62 (56\%) de insuficiência venosa, 38 (34\%) de história anterior de cirurgia de varizes, e $10(9 \%)$ de cirurgia cardíaca prévia com safenectomia.

Dos fatores predisponentes sistêmicos foram encontrados $50(17 \%)$ casos de obesidade, $20(10 \%)$ de diabetes mellitus e 40 (14\%) de hipertensão arterial.

Dos casos analisados, em 75 (26\%) foi detectada a porta de entrada, sendo um caso de úlcera no membro inferior direito, um de trauma no pé direito e 73 de suspeita clínica de dermatofitose sem exame micológico.

A complicação detectada foi a erisipela bolhosa necrotizante, com 15 (5\%) casos, sendo um submetido posteriormente a enxerto da pele.

A antibioticoterapia aplicada a $237(83,5 \%)$ casos utilizou penicilina com eritromicina em $42(15 \%)$ e penicilina com outros antimicrobianos em cinco $(1,5 \%)$; a diosmina foi utilizada como coadjuvante do tratamento em 129 (45\%) casos.

Em relação à necessidade de internação, ela se fez presente em $23(8 \%)$ casos.

\section{DISCUSSÃO}

Em seu estudo os autores puderam perceber que houve predominâmcia do sexo masculino (55\%) em relação ao feminino (45\%), o que diverge do trabalho de Chartier e Grosshans.

Com relação à idade, houve predomínio da faixa etária dos 60 aos 70 anos, e a média foi de 54 anos, constatações compatíveis com a literatura. ${ }^{4,5}$

O local mais acometido pela erisipela segundo a literatura ${ }^{16}$ consultada revelou-se os membros inferiores, assim como apontou este estudo (cerca de 90\%). Segundo Ronnen et al. e Dompmartin, o maior interesse pela estética e higiene facial adequada seria o responsável pelo declínio da localização facial, comum em épocas anteriores.

Além disso, com relação à recorrência da doença, observou-se que a erisipela de repetição ocorreu em $25 \%$ dos casos, o que foi compatível com os dados de Sjoblom et al. $(29 \%)$ e Cricky et al. (23\%).

Lotem et al. relatam o caso de uma mulher de 75 anos que, após 40 anos de erisipela recorrente na mesma
13 to 87-year-old age group, with a mean age in this study of 54 years.

All 284 patients presented erysipelas in the inferior members, although one also presented the disease in the right buttock. Of these cases, 120 (43\%) presented involvement of the left inferior member, 113 (40\%) of the right inferior member and 50 (17\%) of both. It was also observed that 73 (25\%) cases had undergone more than one episode of erysipelas.

Furthermore, 221 (78\%) patients had some predisposing factor. These were classified into local and systemic factors, with 111 (50\%) and 110 (50\%) cases respectively.

Regarding local predisposing factors (111 cases), the authors observed only one (1\%) case of chronic lymphangitis, 62 (56\%) venous insufficiency, 38 (34\%) prior history of surgery for varicose veins, and 10 (9\%) previous heart surgery with saphenectomy.

Of the predisposing systemic factors, there were 50 (17\%) cases of obesity, $20(10 \%)$ of diabetes mellitus and $40(14 \%)$ with arterial hypertension.

The entry site was determined in 75 (26\%) patients, of which there was one case of ulcer in the right inferior member, one of trauma in the right foot and 73 with clinical suspicion of dermatophytosis, though without mycological exam.

The complication detected was bullous necrotizing erysipelas, with 15 (5\%) cases, of which one was later submitted to a skin graft.

The antibiotic therapy administered to 237 (83.5\%) patients used penicillin with erythromycin in 42 (15\%) and penicillin with other antimicrobial agents in five (1.5\%); diosmine was used as an auxiliary to the treatment in 129 (45\%) cases.

A total of 23 (8\%) cases required hospitalization.

\section{DISCUSSION}

In this study the authors detected a slight male bias (55\%), which differs from the work of Chartier and Grosshans.

With regard to age, there was a prevalence in the age group of 60 to 70 years old, and the mean age was 54 years, these findings corroborate the literature. ${ }^{4,5}$

The site most involved by erysipelas according to the literature ${ }^{16}$ consulted was the inferior members, as was found in this study (approximately 90\%). According to Ronnen et al. and Dompmartin, the greater concern for aesthetics and appropriate facial hygiene could be responsible for the reduced incidence in the face, which was common in previous times.

In addition, regarding the recurrence of the disease, this was observed in $25 \%$ of the cases, which was compatible with the data of Sjöblom et al. (29\%) and Cricky et al. (23\%).

Lotem et al. report a case of a 75-year-old woman who, after 40 years of recurrent erysipelas in the same leg, developed multiple $(n=23)$ basal cell carcinomas, even in 
perna, desenvolveu múltiplos (23) carcinomas basocelulares, sem história prévia de radiação ou outros fatores carcinogênicos. Por outro lado, a radioterapia pode favorecer a recorrência da erisipela. A deficiência imunológica e a insuficiência venosa são importantes fatores predisponentes nessa infecção.

Os fatores predisponentes podem ser divididos em locais e sistêmicos, sendo os primeiros representados principalmente pela insuficiência venosa e, menos freqüentemente, pela linfangite crônica. Em seu estudo os autores analisaram como fator local também a cirurgia prévia de varizes, devido às lesões que podem ocorrer no sistema linfático por causa desta operação, como edema, fissuras e infecção. Outro fator local foi a cirurgia cardíaca com retirada da veia safena para revascularização miocárdia, ${ }^{2}$ lesando os linfáticos vizinhos dessa veia e tornando o membro inferior mais suscetível à ocorrência da erisipela. Nos fatores predisponentes gerais encontram-se diabetes, obesidade, hipertensão arterial, fumo e alcoolismo. Os autores consideram a hipertensão arterial um fator agravante devido ao comprometimento do território veno-arteríolo-capilar com obstrução de pequenos vasos, prejudicando a drenagem venosa e predispondo ao edema e infecção. ${ }^{8}$

Neste estudo foi observado que $78 \%$ dos pacientes apresentaram fatores predisponentes sejam locais ou sistêmicos, o que também foi observado por David et al. (65\%). Quanto aos fatores predisponentes locais, foi verificado o predomínio de insuficiência venosa (56\%), o que se aproxima do estudo de outros autores. ${ }^{12}$ Foram observados previamente 38, com $34 \%$ de cirurgia de varizes, e 10 com $9 \%$ de cirurgia cardíaca.

Quanto aos fatores predisponentes sistêmicos, observaram-se $50(17 \%)$ casos de obesidade, citada na literatura, e $10 \%$ de casos de diabetes mellitus, enquanto David et al. encontraram 9\%, e Ronnom et al., 8,3\%.

Os autores consideram de interesse relatar a ocorrência de 40 casos de hipertensão arterial (14\%), contribuindo como fator predisponente sistêmico.

Pode ocorrer com relativa frequiência a recorrência dos episódios de erisipela, e na maioria das vezes isso ocorre por falta de higiene cuidadosa do paciente, não tratamento das micoses interdigitais ou predisposição imunológica à afecção. ${ }^{13,14}$ Nos casos de recidiva, deve ser pesquisada e eliminada a infecção secundária por Staphlilococcus aureus. A erisipela deve ser tratada com antibioticoterapia sistêmica para prevenir complicações. ${ }^{15}$

Cricky et al. encontraram em seu estudo $26 \%$ dos casos com micoses interdigitais - os autores observaram $27,4 \%$ neste -, caracterizando esse fato como porta de entrada para a doença.

Em relação à antibioticoterapia, na maioria dos casos $(237$, correspondendo a $83,5 \%)$ foi utilizada a penicilina benzatina ou cristalina, como referenciada na literatura revisada pelos autores, porém vale ressaltar, que nos casos de alergia à penicilina, fizeram uso de eritromicina em 42 casos (15\%). Empregaram também como coadjuvante a the absence of a prior history of radiation or other carcinogenic factors. On the other hand, radiotherapy can favor the recurrence of erysipelas. Immunological deficiency and venous insufficiency are important predisposing factors in this infection.

The predisposing factors can be divided into local and systemic, the former represented mainly by venous insufficiency and less frequently by chronic lymphangitis. In the present study the authors also considered prior surgery of varicose veins as a local factor since following this operation edema, fissures and infection can occur in the lymphatic system. Another local factor was heart surgery with excision of a saphenous vein for myocardial revascularization, ${ }^{2}$ which can harm the neighboring lymphatics of the vein and thereby rendering the inferior member more susceptible to erysipelas. Among the general predisposing factors are diabetes, obesity, arterial hypertension, use of tobacco and alcoholism. The authors consider arterial hypertension to be an aggravating factor due to involvement of the arteriole-capillary-vein territory, with obstruction of minor vessels, harming the venous drainage and predisposing the individual to edema and infection. ${ }^{8}$

In this study it was observed that $78 \%$ of the patients presented either local or systemic predisposing factors, a fact also observed by David et al. (65\%). As for the local predisposing factors, a prevalence of venous inadequacy was verified (56\%), which is in accordance with the findings of other authors. 12 In addition 38 (34\%) patients had undergone prior surgery of varicose veins and 10 (9\%) heart surgery.

Regarding the predisposing systemic factors, 50 cases $(17 \%)$ of obesity were identified in the literature, furthermore $10 \%$ of cases presented diabetes mellitus, while David et al. found 9\% and Ronnom et al., 8.3\%.

The authors consider the occurrence of 40 cases of arterial hypertension (14\%), to be interesting as this contributes to the systemic predisposing factors.

Recurrent episodes of erysipelas can occur with relative frequency and most of the time this is due to a lack of hygiene on behalf of the patient while treating an interdigital mycosis or immunological predisposition to the disease. ${ }^{13,14}$ In cases of recurrence, secondary infection by Staphylococcus aureus should be tested for and eliminated. Erysipelas should be treated with systemic antibiotic therapy to prevent complications. ${ }^{15}$

Cricky et al., in their study found interdigital mycosis in $26 \%$ of the cases - the present authors observed $27.4 \%$ - characterizing this fact as the entry site of the disease.

In relation to antibiotic therapy, in most of the cases $(n=237,83.5 \%)$ penicillin $G$ benzathine or crystalline penicillin was used, as reported in the literature revised by the authors, however it is worth underscoring that in cases of allergy to penicillin, erythromycin was used in 42 (15\%) cases. Diosmine was also used as a supporting therapy in 
diosmina em 129 pacientes (45\%) e acreditam que seu mecanismo de ação na melhora do quadro seja sua ação flebotônica e linfotônica, aumentando a drenagem linfática, com conseqüente diminuição do edema.

Os $23(8 \%)$ pacientes com toxemia e anorexia necessitaram internação hospitalar para seu tratamento clínico, complementado com repouso e compressas com antissépticos tópicos.

\section{CONCLUSÃO}

Neste estudo clínico os pacientes do sexo masculino foram mais atingidos pela doença, e a faixa etária mais comprometida situou-se entre 60 e 70 anos. As pessoas obesas mostraram-se mais predispostas a contrair erisipela. Os membros inferiores foram os mais acometidos, e a tinha dos pés foi a porta de entrada principal para o agente causal da doença. A complicação mais grave da erisipela configura-se nas bolhas necrotizantes, às vezes demandando internação hospitalar. $\mathrm{O}$ tratamento mais utilizado neste estudo incluiu a penicilina benzatina e cristalina.

\section{REFERÊNCIAS / REFERENCES}

1. Tanaka AMU. Erisipela, Ars Cvrandi out. 1988; 6(2): 79-81. 2. Vogelfrang, D. Linfologia Básica; 1a edição, SãoPaulo: Ícone, 1995 pág 79-81.

3. Bernard PP. Infections cutanées bactériennes: érysipèle. La Revue du Praticien 1996; 10(2):773-6.

4. Chartier MD \& Grosshans MD Erysipelas, Int J. Dermatol, 1990; 29(7):459-66.

5. David G. et al, Erisipela. Evaluaión de 100 casos en el Hospital Universitano de Caracas: PCM, 1991: 5(1):21-3.

6. Ronnen M, Suster S, Schewach-Millet M. , et al., Erysipelas: Changing faces Int J. Dermatol, 1985; 24: 169-72.

7. Sjoblom B. et al., Antibiotic Prophylaxis in Recurrent Erysipelas, Infection, 1993; 21(6): 390-93.

8. Cricky, F. et al., Érysipèle: Données Épidémiologiques, Cliniques et thérapeutiques, Ann. Dermatol. Venereol, 1991; 118:11-16.

9.Lotem, M. et al., Multiple basal cell carcinomas of the leg after recurrent erysipelas and chronic Iymphedema, J. Am. Acad. Dermatol, nov. 1994; 31(5).
129 (45\%) patients and it is believed that the mechanism by which it improves the picture lies in its phlebotonic and lymphotonic action, by increasing the lymphatic drainage, with consequent decrease in the edema.

All 23 (8\%) patients with toxemia and anorexia required hospitalization for their clinical treatment, complemented with rest and compresses with topical antiseptics.

\section{CONCLUSION}

In this clinical study, there was a male sex bias in the disease and the 60 to 70-year-old age group was most affected. Obese individuals were also shown to be more predisposed to contract erysipelas. The inferior members were the most frequently involved and lesions due to tinea pedis were the main entry site for the causal agent of the disease. The most serious complication of erysipelas was necrotizing blisters, which sometimes required hospitalization. The treatment most used in this study included crystalline and $G$ benzathine penicillin.

10. Saiag, P. et al., Recurrent cervical erysipela ocurrig in a irradiated area. Ann. Dermatol. Venereal., 1989; 116(11) 849-50.

11. Santos, I. et al., Predisponing and triggening factors in erysipelas. Dermatology, 1984; 12(5) :399-402.

12. Wanke, N. C. F. et al., Erisipela: estudo retrospectivo de 235 casos. An Bras. Demmatol. 1992; 67(2): 67-9.

13. Cribier, B., Erysipelas and impetigo. Int. J. Dermatology, 1996; 46(13) 1593-8.

14. Zimmerli, W. \& Itim, P. Localized bacterial skin infections and dermatologic manifestation of sistemic infections. Int. J. Dermatol., 1992; 49(4): 250-6.

15. Abrantes, M. A. \& Lavareda, C. A. patient with erysipela, how to treat him? Int. J. Dermatology, 1967; 45(3): 148-56

16. Pitche, P. \& Tchangai - Walla, K., Erysipelas of the leg in hospital environment in low. Int. J. Dermatology, 1997; 90(3):189-91. 17. Dompmartin, A. et al., Sweet syndrome associated with acute wyelogenus leukemia. Atypical from simulating facial erysipelas. Int. J. Dermatol., 1991; 30(9): 644-7.

\footnotetext{
ENDEREÇO PARA CORRESPONDÊNCIA: / MAILING ADDRESS:

Dr. Carlos Henrique de Alvarenga Bernardes

Rua Luiz Suplicy, 73 / Conj. 1 - Gonzaga

Santos SP 11055-330

Tel (13) 3234-9532/3232-3587

E-mail:chab@uol.com.br
} 